\title{
Polluter Pays Principle Terkait Pertanggungjawaban Corporate PTTEP Australasia Terhadap Pencemaran Minyak Di Laut Timur Indonesia
}

\author{
Annisah Dian Utami Panjaitan*; Novianti; Mochammad Farisi \\ Fakultas Hukum Universitas Jambi \\ *Corresponding author: annisahdianutamipitn23@gmail.com
}

$\begin{array}{ll}\text { Submission } & : 25 \text { Januari } 2021 \\ \text { Revision } & : 25 \text { Maret } 2021 \\ \text { Publication } & : 02 \text { Juni } 2021\end{array}$

\begin{abstract}
This research is aimed to analyze and determine the 16th provision principle of the declaration on environment and development, namely the polluter pays principle, as one of the state's form of accountability towards the polluting across borders between PTTEP Australia and Indonesia. This is a juridical research, which analyzes the issue discussed through the use of many realted sources. The polluter pyas principle, as a form of state responsibility in environmental pollution, has some advantages and disadvantages when applied as a recommendation by the OECD (Organization For Economic Cooperation And Development). In the case of cross-border environmental pollution, the principle of good neighborliness and the principle of state responsibility in dealing with pollution cases as a sign of state's goodwill to comply with existing international law. The case of environmental pollution itself is not only the state that can sue, but a group of people or the community can also sue, if they feel harmed by the pollution that occurs. One of them is by carrying out class action in holding accountable for the consequences of pollution that has occurred, and is detrimental to a group or large number of people. even though international environmental law is a soft law, it can become hard law depending on the pollution case that occurs. Even so,
\end{abstract}


international environmental law contained in the Stockholm Declaration, Rio de Jeneiro, civil liability convention and other related international arrangements have been very good in their regulatory fields.

Keywords: Class Action; Polluter Pays Principle; Responsibility.

\begin{abstract}
Abstrak
Penelitian ini bertujuan untuk mengetahui dan menganalisis ketentuan prinsip ke-16 the Rio Declaration on Environment and Development, yaitu polluter pays principle sebagai bentuk tanggung jawab negara terhadap pencemaran lingkungan lintas batas antara PTTEP Australasia (Australia) dan Indonesia. Penelitian ini merupakan yuridis yang meneliti yang meneliti sumber-sumber terkait dengan masalah yang dibahas. Hasil penelitian ini menyimpulkan bahwa polluter pays principle, sebagai salah satu bentuk tanggung jawab negara dalam pencemaran lingkungan memiliki kelebihan dan kekurangan jika diterapkan meski direkomendasi oleh OECD (Organization for Economic Cooperation and Development). Dalam kasus pencemaran lingkungan lintas batas negara sendiri perlu menerapkan prinsip good neighborliness dan prinsip state responsibility dalam menghadapi kasus pencemaran sebagai tanda itikad baik negara untuk mematuhi hukum internasional yang ada. Kasus pencemaran lingkungan sendiri bukan hanya negara yang dapat menggugat tetapi sekelompok orang atau masyarakat dapat ikut menggugat, jika merasa dirugikan akibat pencemaran yang terjadi. Salah satunya dengan cara melakukan class action dalam meminta pertanggungjawaban akibat dari pencemaran yang terjadi, dan merugikan sekelompok atau banyaknya masyarakat. Meski hukum lingkungan internasional merupakan soft law, akan tetapi bisa menjadi hard law tergantung dari kasus pencemaran yang terjadi. meski begitu hukum lingkungan internasional yang terdapat dalam deklarasi Stockholm, Rio De Jeneiro, Civil Liability Convention dan pengaturan internasional terkait lainnya sudah sangat bagus dalam bidang pengaturannya.
\end{abstract} Kata Kunci: Class Action; Polluter Pays Principle; Tanggung
Jawab. 


\section{A. Pendahuluan}

Prinsip pencemar membayar atau polluter pays principle, merupakan salah satu prinsip dalam hukum lingkungan internasional. Pada sekitar tahun 60 dalam the cost of economic growth memperkenalkan polluter pays principle suatu prinsip bagi pencemar yang seharusnya dapat dihindari. Prinsip ini sendiri dianut dan pertamakali dikenalkan oleh negara-negara anggota Organization for Economic Co-peration and Development (OECD) dan juga terdapat dalam ketentuanketentuan Hukum European Communities Tahun 1972. ${ }^{1}$

Prinsip pencemaran membayar pertama kali muncul dalam dokumen yang dipersiapkan oleh International Organization for Economic Cooperation And Development (OECD), yaitu environment economics. Prinsip pencemaran membayar berhubungan dengan pernyataan klasik Plato yang menyatakan if anyone intentionally spoils the water of another... let him not only pay for damages, but purify the stream or cistern that contains the water, jika seseorang dengan sengaja merusak air atau yang lainnya... biarkan dia tidak hanya membayar atas kerugian tetapi membersihkan anak sungai atau waduk yang berisi air. ${ }^{2}$

1 Muhamad Muhdar. Eksistensi Polluter Pays Principle Dalam Pengaturan Hukum Lingkungan. Mimbar Hukum. Vol. 21. No. 1. hal.72.

2 Suparto Wijoyo, A'an Efendi. Hukum Lingkungan Internasional. Jakarta Timur. Sinar Grafika. 2017, hal. 97.

Uti Possidetis: Journal of International Law, Vol. 2, No. 2 (2021) 
Prinsip ke-16 Deklarasi Rio ini sendiri merupakan produk dari Konferensi PBB tentang lingkungan dan pembangunan. Dalam perkembangannya sendiri beberapa perjanjian setelah Deklarasi Rio mewajibkan pihak-pihak perjanjian untuk menerapakan prinsip pencemar membayar ini. ${ }^{3}$ prinsip ini sendiri juga hanya muncul dalam beberapa perjanjian yang terbatas yaitu pada pencemaran saluran air internasional, polusi laut, kecelakaan industry lintas batas, dan energi. ${ }^{4}$

Prinsip ini sendiri juga berkembang menjadi beberapa variasi dari kemunculannya, secara umum sendiri variasi tersebut terbagi menjadi tiga yaitu instrumen pajak pigouvian, instrument ekonomi, dan atur awasi. ${ }^{5}$ implementasi munculnya prinsip pencemar membayar ini sendiri ada untuk menjamin bagi korban yang dirugikan, komisi hukum internasional juga menyarankan prinsip ini untuk menjamin bahwa korban yang menderita akibat kerusakan dari insiden yang berkaitan dengan aktivitas berbahaya mampu mendapatkan kompensasi segara dan memadai. ${ }^{6}$

Implemantasi prinsip ini sendiri paling sering dilakukan negara-negara adalah internalisasi melalui pajak atau denda,

3 Gandar Mahojwalaparipurno. Prinsip Pencemaran Membayar untuk Mendorong Akses Kompensasi di Kebijakan ASEAN dalam Kasus Polusi Kabut Asap Lintas Batas. Junal Hukum Lingkungan. Vol. 4. hal. 115.

4 Ibid.

5 Ibid.

6 Ibid.

Uti Possidetis: Journal of International Law, Vol. 2, No. 2 (2021) 
dan juga aturan tentang pertanggungjawaban melalui hukum perdata maupun publik. Selain merupakan efek jera bagi pencemar, prinsip ini juga dapat mencabut lisensi pencemar, denda, hukuman pidana, pembayaran kompensasi, dan pemulihan lingkungan dimana dapat melengkapi pemenuhan dari prinsip pencegahan. ${ }^{7}$

Salah satu konvensi yang mengatur mengenai tanggung jawab terhadap pencemaran di laut adalah International Convention on Civil Liability for Oil Damage 1969 (CLC 1969). CLC 1969 merupakan konvensi yang dilaksanakan Brussels, 29 November 1969. Konvensi ini secara khusus mengatur mengenai pertanggungjawaban perdata terhadap pencemaran minyak di laut. ${ }^{8}$ Prinsip pencemar membayar ini sendiri dalam hukum lingkungan nasional tidak terdapat secara spesifik, namun dalam Pasal 34 Ayat (1) Undang-Undang Perlindungan Lingkungan Hidup sendiri terdapat pengertian yang hampir mirip dengan prinsip tersebut yang berbunyi :

"Setiap perbuatan yang melanggar hukum berupa pencemaran dan/atau perusakan lingkungan hidup yang menimbulkan kerugian pada orang lain atau lingkungan hidup, mewajibkan kepada penanggung jawab usaha

7 Ibid.

8 Heryandi, Rehulina, T. Jessica Novia Hermanto (Ed). Hukum Laut Internasional dalam Perkembangan. Bandar Lampung. Justice Publisher. 2015. hal.71.

Uti Possidetis: Journal of International Law, Vol. 2, No. 2 (2021) 
dan/atau kegiatan untuk membayar ganti rugi dan/atau melakukan tindakan tertentu."9

Penerapan nyata dari prinsip pencemaran membayar ini sendiri adalah pengalokasian kewajiban ekonomi terkait dengan kegiatan-kegiatan yang merusak lingkungan secara khusus dan berhubungan dengan tanggung gugat atau liability, penggunaan instrument ekonomi dan penerapan peraturan terkait persaingan dan subsidi.

Pemerintah Indonesia bersama-sama dengan Australia bertanggungjawab dalam memelihara dan memberikan perlindungan terhadap lingkungan. Salah satunya adalah meminta tanggung jawab perdata (liability) sesuai dengan hukum kebiasaan internasional, dengan salah satu prinsip yaitu pencemaran membayar (polluter pays principle), dimana sampai saat ini kasus tersebut belum mendapat titik terang atau jalan keluar terhadap pencemaran yang terjadi.

\section{B. Pembahasan}

1. Penerapan Prinsip Pencemar Membayar Terkait Kasus Pencemaran Minyak di Laut yang Melibatkan PTTEP Australia dan Indonesia dalam Upaya Meminta Pertanggungjawaban Akibat Pencemaran yang Terjadi

Secara nasional dalam perundang-undangan Indonesia masalah terhadap dampak lingkungan transional atau lintas batas nasional, mendapat perhatian antara lain dalam Pasal 4

9 Lihat Pasal 34 Ayat (1) Undang-Undang Perlindungan Lingkungan Hidup No. 32 Tahun 2009 
huruf e yang memuat tentang dampak kegiatan yang bersifat lintas batas nasional, juga dalam dalam Undang-Undang Nomor 5 Tahun 1983 tentang Zona Ekonemi Ekslusif Indonesia. ${ }^{10}$ Dapat dikatakan secara umum bahwa pengaturan tentang lingkungan laut yang bersifat lintas batas nasional, telah berkembang sejak tahun 1970 .

Selain itu yang mengatur masalah lingkungan laut, juga terdapat pada Konvensi Jenewa tentang Konservasi Perikanan Dan Kekayaan Laut (Conservation on Fishing and The Living Resources of The High Seas, 1985). Dalam Konvensi Jenewa sendiri tentang landasan kontinen, terdapat beberapa ketentuan yang mengatur tentang kegiatan eksplorasi dan eksploitasi sumber daya alam, dimana mengatur tentang kewajiban negara pantai untuk melakukan upaya perlindungan lingkungan laut.11

Negara-negara sendiri diharuskan untuk mengambil tindakan upaya pencegahan terjadinya pencemaran yang bersifat lintas batas nasional, termasuk dalam memperkirakan waktu yang dijadikan upaya dalam mengurangi atau menghilangkan pencemaran lintas batas nasional.12 tehadap dampak lingkungan lintas batas sendiri dikenakan prinsip

10 Daud Silalahi. Pengaturan Hukum Lingkungan Laut Indonesia dan Implikasinyasecara Regional. Bandung. Penerbit Alumni Bandung. 2014. hal. 185.

11 Ibid., hal. 137.

12 Op.Cit., hal. 189.

Uti Possidetis: Journal of International Law, Vol. 2, No. 2 (2021) 
yaitu prinsip non-dikriminasi, dimana terdapat beberapa poin penting antara lain :

a. Pelaku pencemar yang menimbulkan dampak lintas batas harus dikenakan ketentuan yang sama atau lebih berat dari kententuan negara asal pelaku sendiri.

b. Penerapan tanggung jawab terhadap baku mutu dampak lingkungan yang bersifat lintas batas nasional, tidak boleh melampui baku mutu di negara asal pencemar, seberapa mungkin harus memperhatikan keadaan khusus lingkungan negera yang terkena pencemaran.

c. Apabila dianut pollution pays principle, pelaksanaannya tidak dapat berbeda terhadap negara-negara yang terkena dampak lingkungan yang bersifat lintas batas nasional.

d. Setiap orang yang menderita dari pencemaran lintas batas nasional tidak boleh memperoleh perlakuan yang berbeda dengan seseorang. ${ }^{13}$

Setiap negara sendiri diharapkan tidak melakukan kegiatan proyek yang dapat diperkirakan menimbulkan resiko pencemaran bersekala besar dan lintas batas nasional, untuk itu sangat diperlukannya (extreme urgency).Dalam hal ini sendiri negara wajib menerapkan prinsip penerapan sistem pemberitahuan secara dini (warning system: prior notice) terhadap kecelakan yang terjadi, prinsip saling mengadakan

13 Ibid., hal. 189.

Uti Possidetis: Journal of International Law, Vol. 2, No. 2 (2021) 
pertukaran data ilmiah, penyelesaian pertikaian (dispute settlement), prinsip persamaan untuk didengar, dan perjanjian atau persetujuan internasional dalam menyelesaikan kasus yang mencemari lintas batas negara. ${ }^{14}$

Secara teoritis sendiri, prinsip pencemar membayar pada dasarnya merupakan sebuah kebijakan ekonomi dalam rangka pengalokasian biaya bagi pencemar dan kerusakan lingkungan. Tetapi kemudian memiliki implikasi terhadap perkembangan hukum internasional dan nasional, yaitu terkait tanggung jawab ganti kerugian atau biaya-biaya lingkungan yang harus dipikul. ${ }^{15}$ Teori strict liability sendiri merupakan tanggungjawab orang yang melakukan suatu jenis kegiatan yang digolongkan sebagai abnormally dangerous, maka ia di wajibkan memikul segala kerugian meski telah hatihati untuk mencegah bahaya tersebut. 16

Kasus ledakan ladang minyak Montara yang terjadi pada tahun 2009 sendiri meluas dan masuk kedalam perairan Indonesia, tepatnya di pesisir timur Indonesia yaitu Nusa Tenggara Timur. Dampak dari terjadinya pencemaran tersebut pun merugikan para nelayan pesisir laut timur Indonesia, terutama para petani yang melakukan budidaya rumput laut sangat merasakan dampak akibat tumpahan minyak tersebut.

\footnotetext{
Ibid., hal. 192

15 Malvin Edi Darma. Penerapan Polluter Pays Principle dan Strict Liability Terhadap Pelaku Pembakaran Hutan. Jurnal Hukum Adigama. Hal. 6.

16 Ibid.
}

Uti Possidetis: Journal of International Law, Vol. 2, No. 2 (2021) 
Dalam hasil uji laboratorium sendiri menunjukan bahwa 38,15 persen laut timur Indonesia tercemar tumpahan minyak tersebut.

Produksi petani rumput laut dalam kejadian ini pun menurun, dari yang dulunya sebelum tercemar 7.000 ton per tahun setelah tercemar menjadi 2.000 ton per tahun. Negara Australia sendiri mengakui bahwa tumpahan akibat meledaknya ladang minyak Montara memasuki perairan di pesisir timur Indonesia. Bahkan pihak Australia sendiri melakukan pemantau tumpahan minyak hingga ke wilayah perbatasan dan menemukan adanya gumpalan minyak mentah yang memasuki pesisir laut timur Indonesia.

Sumur minyak Montara sendiri merupakan milik PTTEP Australasia (ashmore cartier) yang berlokasi di Australia Utara yang berjarak $700 \mathrm{~km}$ dari Kota Darwin. PTTEP Australia sendiri merupakan anak perusahaan dari PTTEP exploration and public company limited, karena dinilai sangat merugikan pemerintah Indonesia membuat tim khusus untuk penyelidikan dan pemantauan kasus pencemaran yang terjadi di wilayah timur Indonesia. Pemerintah Indonesia sendiri menggugat PPTEP Australasia di Federal of Court Australia dan meminta kerugian kepada terguggat senilai Rp. 247 Miliar. Menurut menteri perhubungan pada saat itu, nilai ganti rugi tersebut terbilang kecil dari data yang di kumpulkan oleh firma hukum di Australia, yang menilai kerugian akibat pencemaran tersebut mencapai Rp. 5,5 Trilliun. 
Penerapan prinsip pencemar membayar dalam kasus pencemaran sendiri dapat dilakukan terlebih prinsip ini menggunakan instrument ekonomi yang mengarah kepada hukum perdata. Komisi internasional sendiri menyatakan bahwa prinsip pencemar membayar adalah komponen penting dalam menjamin korban yang menderita atas pencemaran yang terjadi, sehingga mampu mendapatkan kompensasi yang segera dan memadai. ${ }^{17}$ Juga prinsip ini lebih mementingkan internalisasi biaya atas kerusakan lingkungan yang terjadi.

Prinsip pencemar sendiri merupakan salah satu komponen penting dalam hak akses untuk upaya perbaikan tingkat nasional terhadap pencemaran. ${ }^{18}$ Hak ini sendiri bertujuan memberikan perlakuan yang sama terhadap korban pencemaran domestik maupun lintas batas, termasuk dalam mengakses informasi, partisipasi dalam pemeriksaan administrative dan proses hukum, dan penerapan standar non-diskriminasi menentukan ilegalitas pencemaran. ${ }^{19}$ Prinsip ini sendiri tidak dapat dipisahkan dari prinsip nondiskriminasi, dimana prinsip non-diskriminasi menekankan penting pemulihan domestik untuk menjamin bahwa keuntungan dari perbaikan dan prosedurnya diperluas hingga penggugat lintas batas. ${ }^{20}$

$\begin{array}{ll}17 & \text { Loc.Cit. } \\ 18 & \text { Ibid. } \\ 19 & \text { Ibid. } \\ 20 & \text { Ibid. }\end{array}$

Uti Possidetis: Journal of International Law, Vol. 2, No. 2 (2021) 
Eksistensi prinsip pencemar membayar sendiri dalam penerapan ekonomi juga memiliki kelemahan, yaitu dalam segi pembayaran yang digantungkan pada besar kecilnya jumlah pencemaran yang terjadi. Sehingga pengenaan pajak lingkungan sendiri tidak efektif dan akan menyebabkan dampak negative bagi kesejahteraan sosial. ${ }^{21}$ Prinsip pencemar membayar sendiri dalam sudut pandang hukum harus dinormatifkan melalui pengaturan yang jelas. Penegasan prinsip ini sebagai pertanggungjawaban hukum dimana merupakan bagian dari sistem hukum perdata, maka penentuan ganti kerugiannya pun seharusnya tidak di dasarkan Pada seberapa besar kerugian tetapi mencakupi valuasi ekonomi lingkungan. ${ }^{22}$

Pembebanan biaya berdasarkan prinsip pencemar membayar sendiri akan menjadi lebih jika diikuti dengan penentuan pembayaran, jumlah pembayaran dan tujuan pembayar dari pencemaran lingkungan yang terjadi. Argumen ini sendiri didasarkan pada pertimbangan, dimana selama ini cara menentukan nilai kerugian akibat pencemaran lebih kepada penentuan nilai dari kerugian korban tanpa mengikutsertakan nilai komponen lingkungan hidup. ${ }^{23}$ Penerapan prinsip ini dalam pertanggungjawaban sendiri memiliki kelemahan terutama dalam pembuktian yang tidak kuat, terlebih dalam meminta pertanggungjawaban corporate

\footnotetext{
21 Op.cit., Muhamad Muhdar. hal. 73

22 Ibid.

23 Ibid.
}

Uti Possidetis: Journal of International Law, Vol. 2, No. 2 (2021) 
dimana perusahaan atau badan hukum itu sendiri memiliki sistem dalam memperkirakan terjadinya pencemaran.

Convention on Civil Liability sendiri menerapkan sistem pertanggung jawaban berdasarkan strict liability principle, dimana pelaku pencemar bertanggungjawab mutlak terhadap pencemaran atas tumpahan minyak yang terjadi, tanpa harus dibuktikan adanya unsur kesalahan terlebih dahulu. Penerapan strict liability principle sendiri bertujuan, dapat memperpendek dan meringkas proses kompensasi serta dapat ditanggulangi kondisi masyarakat sekitar yang terkena dampak akibat pencemaran. ${ }^{24}$ Sistem strict liability sendiri memiliki kekhususan dibandingan sistem liability based on fault, dimana proses pembuktian hukum lebih sederhana dan lebih pendek pada strict liability. Hal yang sering terjadi dan merupakan faktor penyulit adalah klaim ganti kerugian, namun demikian proses ganti kerugian yang menjadi terbatas karena sisi lain strict liability, yaitu suatu plafond/ceiling dari jumlah ganti rugi. ${ }^{25}$

Penyelesaian kasus pencemaran ini oleh tim khusus tidak menerima adanya penyelesaian kasus diluar pengadilan, dikarenakan dalam hal lingkungan terutama laut sangat sensitif apalagi pencemaran yang terjadi bukan hanya merugikan masyarakat sekitar tetapi juga perekonomian daerah setempat. Dalam hal melakukan upaya preventif

\footnotetext{
24 Op.Cit.

25 Op.Cit.
}

Uti Possidetis: Journal of International Law, Vol. 2, No. 2 (2021) 
sendiri membutuhkan waktu untuk memulihkan kembali keadaan laut yang tercemar seperti semula. Untuk itu pencemar membayar (must be pay) merupakan salah satu langka yang dapat dilakukan untuk memperbaiki lingkungan yang mengalami kerusakan ataupun menggati kerugian yang terjadi akibat pencemaran.

International Convention on Oil Pollution Preparedness Response and Co-operation yang disetujui Oleh The International Maritime Organization (IMO) sendiri, menyatakan dengan tegas bahwa prinsip pencemar membayar sebagai prinsip umum hukum lingkungan internasional, juga terdapat dalam Preamble Convention on The Transboundary Effects of Industrial Accidents. ${ }^{26}$ Dalam hal ini sendiri Indonesia melakukan langkah yang tepat dalam meminta ganti kerugian akibat pencemaran yang terjadi, terlebih kerugian yang terjadi sangat merugikan masyarakat maupun lingkungan laut yang tercemar .

Pada tahun 2010 pemerintah Indonesia sendiri mencabut gugatan kasus pencemaran yang terjadi, dikarekan ingin mengumpulkan kembali bukti yan kuat dari bukti yang sebelumnya, yang dikatakan kurang untuk menuntut pencemaran yang terjadi. Masyarakat pun kecewa dengan sikap pemerintah, terlebih kasus ini pun mandet dan tidak berjalan bahkan perlu 10 tahun lamanya agar kasus ini terus disidangkan sesuai dengan tuntutan masyarakat. Dalam hal ini

26 Ibid., hal. 98.

Uti Possidetis: Journal of International Law, Vol. 2, No. 2 (2021) 
tindakan pemerintah sebenarnya sudah sangat tepat dalam menuntut pertangungjawaban akibat pencemaran akan tetapi, langkah yang dilakukan lambat dan tuntutan yang di minta menjadi tidak efektif.

Perlindungan pelestarian lingkungan laut mendapatkan perhatian serius oleh hukum interenasional, terutama melalui pengaturan UNCLOS 1982. Dimana dalam pasal 192 konvensi ini menegaskan bahwa setiap negara mempunyai kewajiban untuk melindungi dan melestarikan lingkungan lautnya. Karena itulah, konvensi ini mewajibkan setiap negara untuk mencegah, mengurangi, dan mengendalikan pencemaran lingkungan laut yang terjadi di wilayahnya.

2. Upaya Hukum Penyelesaian Class Action yang Diajukan Petani Rumput Laut Terhadap PTTEP Australasia Berupa Ganti Kerugian dapat Terpenuhi Terkait Pencemaran Minyak di Pesisir Laut Nusa Tenggara Timur Indonesia.

Class action sendiri merupakan gugatan perwakilan kelompok yang terdiri dari unsur wakil kelas yang berjumlah satu orang atau lebih (class representative) dan anggota kelas yang berjumlah besar (class member), dimana keduanya merupakan pihak yang mengalami kerugian. ${ }^{27}$ sedangkan legal standing sendiri pihak yang dapat mengajukan hanya Lembaga Swadaya Masyarakat (LSM), juga dalam hal ganti kerugian class action pada umunya berupa ganti rugi uang

27 Ibid., hal. 8.

Uti Possidetis: Journal of International Law, Vol. 2, No. 2 (2021) 
sedangkan legal standing tidak dikenal tuntutan ganti kerugian uang. 28

Dalam class action sendiri memiliki keuntungan dan kerugian, dari segi keuntungan class action sendiri proses perkara menjadi sangat ekonomis (judicial economy), akses terhadap keadilan terhadap perkara jadi lebih mudah (access to justice) dan merubah sikap pelaku pelanggaran agar dapat bersikap hati-hati (behavior modification). Adapun kerugian atau kekurangan dari class action sendiri yaitu kesulitan dalam mengelola anggota jika terlalu banyak, dapat menyebabkan ketidakadilan dalam anggota kelompok, dapat menyebabkan kebangkrutan pada tergugat dan publikasi gugatan class action dapat menyudutkan pihak tergugat. ${ }^{29}$

Tahun 1996 sendiri sebelumnya Indonesia dan Australia telah memiliki kerangka hukum dalam menyelesaikan kasus di dalam bidang lingkungan, berupa sebuah Memorandum of Understanding ( $M o U$ ) between The Government of Australia and Indonesia on Oil Pollution Preparedness and Response 1996. Dalam kasus pecemaran yang melibatkan PTTEPAA yang bertempat di Montara, Australia, negara Australia sendiri menyikapi dengan itikad baik dan mengupayakan agar PTTEPAA dapat bertanggungjawab atas pencemaran yang terjadi. ${ }^{30}$ Tuntutan

28 Ibid.

29 Op.,Cit, hal. 6

30 Ni Putu Suci Meinarni. Upaya Hukum Dalam Penyelesaian Sengketa Pencemaran Lingkungan Laut Dalam Kasus Tumpahan 
yang diminta Indonesia pun sesuai dengan Civil Liability Convention 1992, dimana kedua negara baik Indonesia dan australia telah meratifikasi konvensi tersebut. Sebelum adanya tuntutan terhadap Australia, Indonesia terlebih dahulu melakukan negosiasi sesuai dengan MoU yang disepakati sebagai implementasi, yang memungkinkan dapat menyelesaikan kasus pencemaran minyak yang terjadi. ${ }^{31}$

Polluter pays principle memang disarankan dalam hal pencemaran yang terjadi, terlebih melibatkan lingkungan terutama lingkungan laut, dan juga dampak dari pecemaran tidak hanya dari segi sosial tetapi juga dari segi ekonomi mereka yang terdampak akibat pencemaran yang terjadi. Ditambah polluter pays principle diperkuat dengan adanya konvensi-konvensi seperti Deklarasi Stockholm 1972, Deklarasi Rio De Jeneiro 1992 dan Civil Liability Convention 1969/1992. Sebenarnya dalam penyelesaian ganti rugi terhadap pencemaran dapat dilakukan dengan Fund Convention 1992 dimana sebagai pelengkap dari Civil Liability Convention 1992.32

Fund Convention sendiri menyediakan kompensasi terhadap dampak dari pencemaran lingkungan yang terjadi. Kompensasi yang disediakan maksimal \$192 juta ganti rugi ini sesuai dengan ketentuan yang berada di Civil Liability

Minyak Montara Di Laut Timor. Jurnal Magister Hukum Udayana. Desember 2016. Vol. 5, No. 4. hal. 860.

31 Ibid., hal. 865

32 Op.Cit., hal. 253.

Uti Possidetis: Journal of International Law, Vol. 2, No. 2 (2021) 
Convention 1992.33 pembayaran kerugian yang disediakan bertujuan agar dapat menjamin pemulihan hak masyarakat yang terdampak, juga pemulihan lingkungan untuk mencegah kerusakan yang lebih parah.

Indonesia sendiri sebenarnya juga merupakan anggota dari Fund Convention 1992, tetapi menarik diri sebagai pihak melalui KEPPRES No. 41 Tahun 1998 dikarekan Indonesia terbebani dengan iuran atau kompensasi yang harus dibayarkan ke IOPC Fund setiap tahunnya. ${ }^{34}$ Negara beralasan bahwa seharusnya industri minyak yang melakukan iuran kepada fund convention dan negara hanya berkewajiban melaporkan penerimaan minyak setiap tahunnya yang dimuat melalui laut. Indonesia sendiri sebenarnya dapat mengajukan ganti rugi kepada Civil Liability Convention 1992, akan tetapi ganti kerugian tersebut hanya dapat membantu sedikit dan tidak sebanyak yang dibayarkan oleh Fund Convention. ${ }^{35}$ Sehingga ganti kerugian yang didapat dari Civil Liability Convention 1992 sendiri tidak maksimal dalam menutupi kerugian maupun kerusakan yang terjadi akibat pencemaran minyak.

Penerapan polluter pays principle sebagai salah satu solusi meminta pertanggungjawaban lingkungan dalam class action sendiri dapat dilakukan, terlebih pencemaran minyak sendiri berkaitan dengan tanggung jawab mutlak (strict

\footnotetext{
33 Ibid., hal. 253

34 Ibid., hal. 254

35 Ibid., hal.255
}

Uti Possidetis: Journal of International Law, Vol. 2, No. 2 (2021) 
liability) yang juga berkaitan pada prinsip pencemar membayar dan prinsip upaya preventif di dalam pencemaran lingkungan. Meski sulit dalam melakukan pembuktian terlebih dalam pembuktian kelalaian, akan tetapi tidak menutup kemungkinan bahwa penerapan prinsip pencemar membayar dapat terlaksana tergantung dengan seberapa besar kasus dan kerugian yang terjadi. Hakim dalam persidangan pasti memutuskan dengan baik jika polluter pays principle tidak dapat diterapkan dalam kasus pencemaran lingkungan, salah satunya dengan melihat putusan yang terdahulu atau doktrindoktrin yang berkaitan. Artinya polluter pays principle ini sendiri dapat diterapkan tergantung dengan besar kecil pencemaran yang terjadi juga, seberapa besar kerugian yang diakibatkan oleh pencemaran tersebut.

\section{Penutup}

Penerapan dari prinsip pencemar membayar sebagai upaya penegakan lingkungan sendiri masih memiliki banyak kelemahan, terlebih prinsip ini sendiri dalam hukum nasional Indonesia penerapannya belum efektif sebagai salah satu bentuk penegakan hukum. Meski begitu prinsip pencemar membayar ini sangat disarankan sebagai salah satu penegakan hukum di bidang pencemaran lingkungan. Juga prinsip ini menjamin agar korban yang dirugikan dapat diberikan ganti kerugian atau kompensasi atas pencemaran yang terjadi. Kelemahan dari prinsip ini 
yaitu penerapan seberapa besar kerugian yang akan dibayarkan, sehingga tak jarang banyak kasus yang memakai penerapan ini sendiri terjadi victim pays. OECD sendiri mengakui beberapan kasus yang menggunakan prinsip ini menjadi victim pays, sehingga pembayaran kerugian terkadang tidak sesuai dengan konsep polluter pays principle.

Pencemaran lingkungan terlebih pencemaran dalam kategori minyak, bentuk tanggung jawabnya adalah strict liability. Prinsip ini sendiri merupakan penerapan yang sangat penting terlebih berkaitan dengan kasus pencemaran. Dengan digunakannya prinsip strict liability sendiri dapat meminimalisir penderitaan yang di alami korban pencemaran, prinsip ini sendiri ada untuk mengatasi keterbatasan pertanggungjawaban kesalahan untuk mengantisipasi kegiatan yang beresiko besar terhadap pencemaran lingkungan. Meski memiliki kelamahan dalam bidang pembuktian pencemaran, prinsip ini sendiri merupakan prinsip penting dalam tanggung jawab lingkung, terlebih prinsip ini menerapkan pertanggungjawaban secara langsung saat pencemaran itu terjadi.

\section{Referensi}

\section{Instrumen Hukum}

Convention on Civil Liability for Oil Damage 1992 (CLC 1992)

Deklarasi Stockholm 1972 
Deklarasi Rio De Jeneiro 1992

Konvensi Hukum Laut 1982 (UNCLOS 1982)

Undang-Undang Nomor 32 Tahun 2009 Tentang Perlindungan Pengelolaan Lingkungan Hidup

\section{Buku}

Silalahi, Daud. Pengaturan Hukum Lingkungan Laut Indonesia dan Implikasinya secara Regional. Jakarta. Pustaka Sinar Harapan. 1992.

Wijoyo, Suparto dan A'an Efendi. Hukum Lingkungan Internasional. Jakarta Timur. Sinar Grafika. 2017.

\section{Artikel}

Darma, Malvin Edi. Penerapan Polluter Pays Principle dan Strict Liability Terhadap Pelaku Pembakaran Hutan. Jurnal Hukum Adigama.

Gandar Mahojwala Paripurno. Prinsip Pencemaran Membayar

Untuk Mnedorong Akses Kompensasi Di Kebijakan ASEAN Dalam Kasus Polusi Kabut Asap Lintas Batas. Jurnal Hukum Lingkungan. Vol. 4. 2018.

Heryandi, et al. Hukum Laut Internasional Dalam Perkembangan. Justice Publisher. 2015.

Meinarni, Ni Putu Suci. Hambatan Dalam Penyelesaian Sengketa Kasus Minyak Montara. Jurnal Komunikasi Hukum. Universitas Pendidikan Ganesha Singaraja. Vol. 3. No. 2. 2017.

Meinarni, Ni Putu Suci. Upaya Hukum Dalam Penyelesaian Sengketa Pencemaran Lingkungan Laut Dalam Kasus Tumpahan Minyak Montara Di Laut Timor. Jurnal Magister Hukum Udayana. Vol. 5. No. 4. 2016.

Muhdar, Muhammad. Eksistensi Polluter Pays Principle Dalam Pengaturan Hukum Lingkungan. Mimbar Hukum. Vol. 21. No. 1. 2009. 